\title{
Beyond governance: the need to improve the regulation of international sport
}

\section{Jean-Loup Chappelet}

To cite this article: Jean-Loup Chappelet (2017): Beyond governance: the need to improve the regulation of international sport, Sport in Society

To link to this article: https://doi.org/10.1080/17430437.2018.1401355

$$
\text { 曲 Published online: } 29 \text { Nov } 2017 .
$$

Submit your article to this journal ${ }^{\pi}$

Q View related articles $\sqsubset$

View Crossmark data $\nearrow$ 


\title{
Beyond governance: the need to improve the regulation of international sport
}

\author{
Jean-Loup Chappelet \\ Swiss Graduate School of Public Administration (IDHEAP), University of Lausanne, Lausanne, Switzerland
}

\begin{abstract}
Governance has been a prominent word in international sport circles since the beginning of the twenty-first century. However, better governance will not cure all the ills of this wide-ranging sector and its numerous governing bodies, many of which, including the International Olympic Committee (IOC), the Fédération Internationale de Football Association (FIFA) and the International Association of Athletics Federations (IAAF), have been shaken by corruption. This paper discusses the need for a new approach to sports governance that combines aspects of both corporate and democratic governance. It also shows that combating problems such as doping, match-fixing, hooliganism and sport corruption requires a wider international legal framework, developed through cooperation between government authorities and the sports sector. Only international regulation will ensure sport gains the improved governance it needs in order to preserve its integrity and value in the eyes of the public.
\end{abstract}

\section{Introduction}

It is now almost two decades since people started talking about governance in the Olympic system. The word first caught on in the world of sport during the 'Salt Lake City scandal', which shook the International Olympic Committee (IOC) at the end of 1998 and throughout 1999 (Wenn, Barney, and Martyn 2011). The outcry over inducements paid to several IOC members by Salt Lake City's 2002 Winter Olympics bid committee led the IOC to profoundly reform its governance (Chappelet 2012). Since then, many of the international sport federations (IFs) within the Olympic system have been tarnished by corruption scandals of varying degrees of seriousness. Most recently, in 2015 and 2016, it has been the turn of two of the world's biggest IFs, the Fédération Internationale de Football Association (FIFA) and the International Association of Athletics Federations (IAAF) to be hit by scandal. Since the beginning of the twenty-first century, governmental and intergovernmental bodies, national and international sport governing bodies and academics have put forward numerous lists - more than 30 in total - of governance principles for sport organizations. However, scandals have continued to emerge. Nevertheless, the FIFA and IAAF scandals appear to have been a turning point. 
The present article shows that preoccupations referred to under the term governance need to be examined from a much wider perspective, that of the regulation of international sport. Although international sport has its critics, it is a vitally important area that has a unique ability to promote peaceful coexistence and cooperation between people and countries. I begin this paper by presenting the current situation in sports governance. I then outline four possible scenarios for monitoring this governance and discuss three important governance questions that are rarely addressed. Section three describes a theoretical model of governance in which state supervision is a key component in improving the regulation of international sport. The paper concludes with a proposal for a long-term solution for introducing the regulation international sport needs in order to preserve its integrity and socio-educational value in the eyes of the public.

\section{The state of sports governance}

Following the Salt Lake City scandal, which led to the expulsion or resignation of ten IOC members in 1999 (and warnings for another ten), several international sport federations have been shaken by revelations of corruption. For example, between 2004 and 2008, the presidents of the IFs for volleyball (FIVB), judo (IJF) and taekwondo (WTU) had to resign both their federation presidencies and their seats on the IOC. Since then, many other 'affairs', some better known than others, have come to light in other IFs, including boxing (AIBA), cycling (UCI), handball (IHF) and weightlifting (IWF), to name just the Olympic federations. Most recently, it has been the turn of the football (FIFA), athletics (IAAF) and shooting (ISSF) federations to be racked by scandal (AFP 2015). These 'affairs' and 'scandals' often result in a change of president.

Although these issues receive little media attention unless they affect a 'major' sport such as football, athletics or cycling, they have resulted in experts and academics taking a close interest in the governance of sport organizations. Hence, the European Union included a list of principles of 'good governance' for the sports movement in its 'Declaration of Nice' in 2000, (EU 2000) and, in January 2001, at a conference on governance held in Brussels by the European Olympic Committees and the International Automobile Federation, Jacques Rogge launched his bid for the IOC presidency by highlighting his position on governance: 'Since Sport is based on ethics and competition on fair play, the governance of sport must comply with the highest standards in terms of transparency, democracy and accountability' (EOC 2001). The research community also made a substantial contribution. For example, Henry and Lee (2004) suggested seven principles for sports governance: Transparency, Accountability, Democracy, Social Responsibility, Equity, Effectiveness and Efficiency. In fact, 35 lists of governance principles had been published by 2013 (Chappelet and Mrkonjic 2013), not including the list published that year by the European Union (EU 2013).

There is now a general consensus that sports governance should combine elements of corporate governance, as applied in the business world (Mallin 2011), and democratic governance, as advocated for the public sector, most notably by the World Bank (Bevir 2010). In fact, sport organizations blend certain characteristics of commercial organizations (especially when they sell broadcasting or marketing rights for their events) with those of public organizations (when they draw up rules for their sports and their events).

In addition to this consensus on the general outline of sport governance (Figure 1), it is now accepted that setting out principles or guidelines is insufficient without an effective 


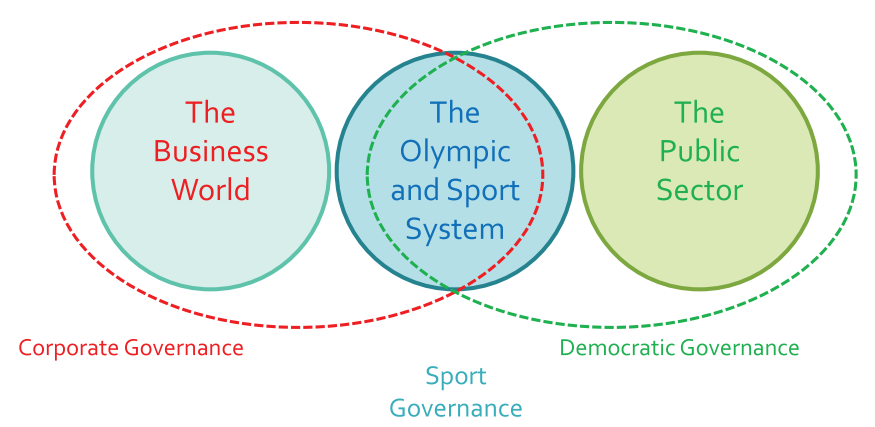

Figure 1. Sport governance at the intersection of corporate and democratic governances (after Henry and Lee 2004).

method for evaluating the governance of individual sport organizations. The first true set of governance indicators was the Basic Indicators for Better Governance of International Sport (BIBGIS), published by Chappelet and Mrkonjic in 2013, although the IOC's 'Basic Universal Principles of good governance of the Olympic and sports movement' (IOC 2008) could be considered a governance checklist. Known as the BUPs, this long catalogue of some 120 guidelines (mostly expressed as recommendations) was drawn up in 2008 and approved by the Olympic Congress in 2009. In contrast, the BIBGIS consists of 63 indicators covering seven areas of governance: Organisational transparency, Reporting transparency, Stakeholders' representation, Democratic process, Control mechanisms, Sport integrity and Solidarity. In 2015, the Danish organization Play the Game published its Sports Governance Observer, which uses 36 indicators to assess four areas of governance (Geeraert 2015). Also in 2015, the Australian government introduced 20 mandatory principles for sports governance (AIS 2015) and Sport England began promoting its Governance Strategy (SE, n.d.). National governing bodies in both these countries have to implement these guidelines in order to continue receiving government subsidies. At the end of the same year, the UK government's strategy for sport (HMG 2015) called for a new governance code in the UK (section 8.4, pages 64, 65). In May of the following year, Britain's prime minister, David Cameron, hosted an anti-corruption summit in London. His wish that the summit also address sport resulted in the two government agencies responsible for elite and grassroots sport publishing a Charter for Sports Governance (UK Sport \& Sport England 2016). In fact, this charter is merely a precursor to a new code of governance for sport organizations, which is due to come into effect in 2017 but which was not ready for publication at the time of the summit.

Finally, in 2016, the General Assembly of the Association of Summer Olympic International Federations (ASOIF) endorsed 50 governance indicators covering five key principles (ten indicators for each principle: Transparency, Integrity, Democracy, Sports development and solidarity, and Control mechanisms), drawn up by an ad hoc taskforce (ASOIF 2016). The IFs within the ASOIF must now assess whether these indicators are respected in their organization. These audits will be in addition to the financial audits required under Swiss law (article 69b of Switzerland's Civil Code) for large IFs based in Switzerland. The IOC demanded the introduction of such a monitoring system as a way of ensuring the large sums it distributes to the IFs from Olympic Games revenues are used appropriately (IOC 2015). At the same time (IOC 2015), the IOC's Executive Board asked 
the Institute of Management Development (IMD), a business school based in Lausanne, to audit the IOC's governance.

Governance has to be monitored over time in order to determine whether it is improving. Rather than the 'good governance' so often alluded to since the World Bank first popularized the term, the objective should be to ensure 'better governance' within each organization. The focus should be on helping sport organizations improve, not on producing meaningless rankings based on comparisons between very different, and therefore fundamentally incomparable, sport organizations.

\section{Monitoring of sports governance}

Carrying out such regular monitoring, which focuses mainly on internal operations, is not always easy, as is shown by the difficulties encountered by FIFA's Audit and Compliance Committee (ACC). In fact, concerns over his independence led the chair of the ACC to resign in May 2016 (Gibson 2016) as he could be removed by a simple vote of the FIFA Council.

Four scenarios can be envisaged for carrying out this monitoring. The first scenario is for each sport organization to set up an internal entity to monitor its entire range of activities (not just its finances, although this is central). This is what the World Bank did when it created the World Bank Inspection Panel (WBIP), which assesses all the projects the Bank finances, some of which have been accused of corruption and of not promoting sustainable development. Such auditing entities must be independent and linked to the host organization's governing body, which must appoint members either permanently or on long-term mandates. Recent reforms within FIFA included the creation of such an entity, named the Audit and Compliance Committee, a step the body responsible for overseeing FIFA's reform process, the Independent Governance Committee, considered essential (See Scala's chapter in Pieth 2014). In 2007, The IAAF, as part of its governance reforms, created the Athletics Integrity Board and Unit to support its work in the field of integrity, including doping but also corruption, match-fixing, etc. This 4 -member Board is elected by the IAAF Congress (of national associations = IAAF members) and reporting to it on a regular basis

The second scenario is to entrust monitoring to outside specialists, for example, one of the 'big four' accounting firms. In Switzerland, appointing external auditors has been obligatory since 2005 for nonprofit associations (most international sport organizations are associations) that exceed two of three thresholds set by Swiss law (article 69b of the Civil Code): turnover of more than CHF20 million; assets of more than CHF10 million; more than 50 employees. Such an audit should go beyond financial aspects and be totally independent, which is difficult to achieve because the auditor receives its remuneration from the organization it is auditing. For example, questions are still being asked about the absence of warnings from FIFA's external auditors prior to 2015 (KPMG) or, perhaps, the failure to act on these warnings. In fact, KPMG resigned as FIFA auditors in 2016 because of the potential systemic risk to its reputation.

The third scenario is to create a specialist body to monitor and help improve the governance of all international sport organizations. The World Anti-Doping Agency (WADA), set up in 1999 to coordinate the global fight against doping, could provide a model for such a body. In fact, many people continue to call for the creation of a World Anti-Corruption Agency (WACA) or for a less constraining International Sport Integrity Partnership (ISIP). 
Because creating this type of monitoring or surveillance organization or scheme would undoubtedly generate resistance and apprehension, it would probably be necessary to conclude an international convention (as was done for WADA) to ensure public authorities across the globe cooperate in the fight to eliminate what can be termed 'the dark side of sport'. Switzerland, as the main host of international sport organizations, could sponsor such a convention. Another long-standing example of cooperation in the world of international sport is provided by the Court of Arbitration for Sport (CAS), which was set up in 1983 under Swiss law and whose authority is now accepted by all Olympic sport organizations, including FIFA (last IF to accept).

The fourth scenario is a sort of compromise between the second and third scenarios. It is inspired by the audits of intergovernmental organizations within the $\mathrm{UN}$, which involve appointing auditors on the basis of regular calls for tenders from specialist national auditing bodies known for their independence and impartiality. For example, in recent years the World Intellectual Property Organization (WIPO) has been audited by Switzerland's Federal Audit Office, which, in this case, reports to the member states that form WIPO's governing body (and to the public via WIPO's website). Hence, member states receive assessments and recommendations that do not originate from the organization's management or a private service provider whose conclusions may not be entirely impartial.

All of these scenarios involve costs, but they could also generate savings and synergies for sport organizations if they could pool their efforts as they do in anti-doping with the Sport-Accord dedicated unit. They can be implemented in parallel and on a voluntary basis, which would facilitate their adoption. However, one thing is clear: the status quo has become untenable and, given the damage done to the reputation of international sport in 2015 and 2016, a solution must be found very quickly.

In addition, there are three important questions relating to sports governance that have almost never been addressed. The first is the use of funds distributed to the members of IFs (national federations) or Olympic stakeholders (mostly IFs and National Olympic Committees - NOCs). Are these funds being used 'correctly' in order to develop sport? Is there not a risk they may end up in the pockets of local sports administrators? To mitigate this risk, the IOC's NOCs Relations Department has developed a self-assessment tool called UMAP (Understanding, Managing, Auditing, Planning), which is available online to all NOCs around the world.

The second question concerns the fact that, in nearly all sport organizations, the president is responsible for running both the organization's regulation activities (under the board's control) and its business activities. This trend was started by Samaranch, when he became president of the IOC in 1980 (Chappelet 2014), and by Blatter, when he was elected president of FIFA in 1998. In other words, in most sport organizations, the CEO is also the chairman of the board, a state of affairs that is frowned upon by many corporate governance guidelines (see, for example, The UK Corporate Governance Code, June 2010, section A.3.1), even though this issue remains open to debate in the literature (e.g. Tonello 2011). A candidate to the FIFA presidency in 2016 proposed that the roles of regulation and commercialization be clearly separated by creating two different organisations in charge of each roles, but he was not elected.

The third question arises from the way host cities (or, in some cases, countries or national federations) for major sports events are chosen. The attribution of major events has generated numerous scandals that have led to governance reforms (selection of Salt Lake City 
to host the 2002 Winter Olympics, selection of Qatar for the 2022 Football World Cup, selection of host cities for the World Championships in Athletics, etc.). Depending on the statutes of the organizations in question, host cities tend to be chosen by a small number of electors (around 100 at the IOC, 200 at FIFA, 20 at the IAAF), which makes the system more susceptible to corruption. One solution would be to greatly increase the number of electors by expanding electorates to include, for example, former Olympians (athletes who have taken part in the Olympics), former players in the World Cup, athletes or fans, etc. Such a massive increase in the number of voters would substantially reduce the risk of corruption. No organization has, as yet, contemplated such a reform, as it would have to be approved by the very people who currently choose host cities/nations/federations and who would thereby lose some of their power. But such a reform could be adopted for future decisions, thereby delaying the loss of power and the resistance of current voters. FIFA's response, as part of its 2015 governance reforms, was to transfer this electoral power from its executive committee ( 25 members) to the FIFA Congress (209 members in 2015), which, unsurprisingly, was happy to approve a reform that gave it more power.

\section{A useful model of governance}

Pérez's (2003) model for corporate governance provides a useful template for analysing sports governance because it differentiates between five levels of governance, from dayto-day management to the legal framework governing an organization's operations. This model (Figure 2) was designed to address five fundamental questions concerning corporate governance. Although it was drawn up for the business sector, it can also be applied to sport organizations.

Applying this model to the IOC produces the following pyramid (see Figure 3), following the reforms introduced in 1999 in the wake of the Salt Lake City scandal (for more details, see Chappelet 2012).

The first three levels of Pérez's model depend mostly on internal structures and statutes set up by the organization in question. In contrast, the top two levels (4 and 5) require government supervision via national or international law.

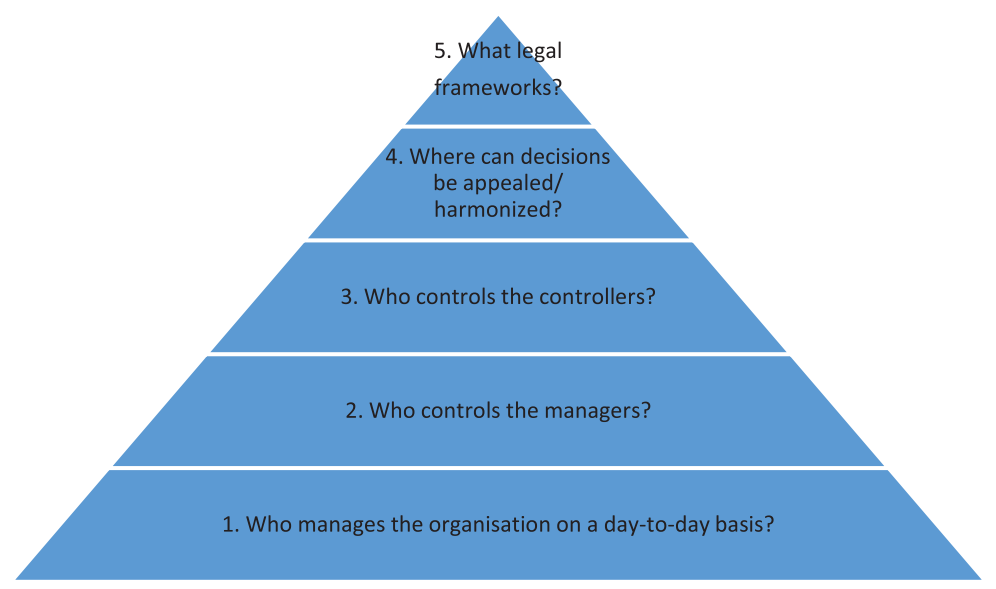

Figure 2. The five questions associated with Pérez's five levels of governance. 


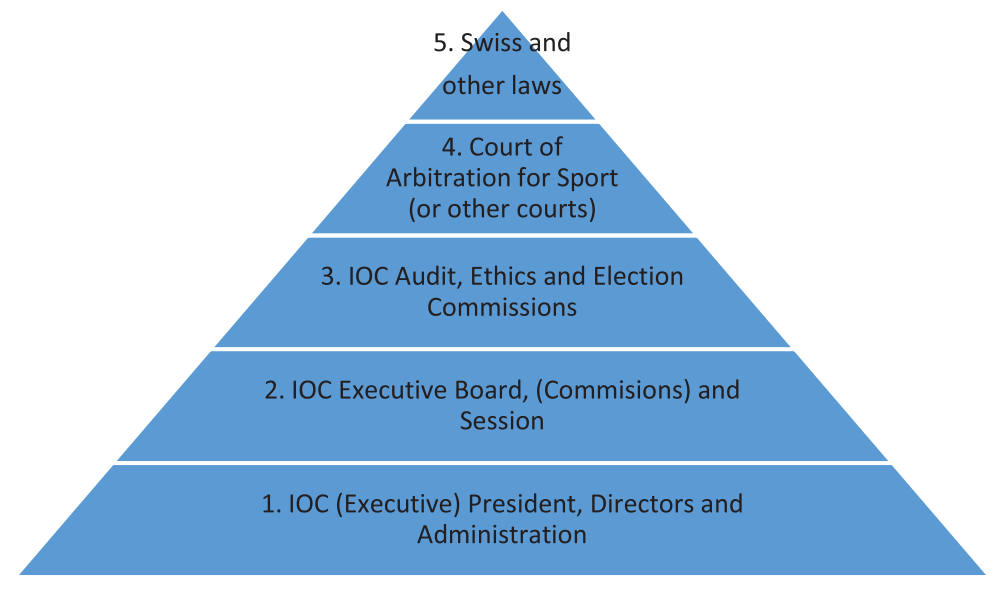

Figure 3. Pérez's model applied to the IOC.

The IOC falls mostly under the jurisdiction of Swiss law because, like many other international sport organizations, it is based in Switzerland and subject to articles 60-79 of the Swiss civil code (for Swiss nonprofit associations). It is also subject to other Swiss laws and to the Court of Arbitration for Sport (set up under chapter 12 of the Swiss federal law on international private law), which is recognized by all the IFs of Olympic sports as the supreme body for settling sport related disputes. Olympic sports organizations accept the need to collaborate with national governments, as long as they retain their autonomy. The 'price' they pay for this autonomy is an obligation to implement 'good governance' (see, for example, point 7 of the BUPs: 'Harmonious relations with governments while preserving autonomy', IOC 2008).

Currently, there is little international legislation that can be directly applied to sport. The exceptions to this rule fall into four areas and are covered by four international treaties/ conventions:

- Sports events spectator violence (Council of Europe 1985), integrated safety (Council of Europe 2016).

- Doping (UNESCO 2005).

- Match-fixing (Council of Europe 2014).

- (Public and private) corruption (United Nations 2003).

However, there is an increasing tendency for governments that have ratified these treaties to draw up or amend national laws in order to cover sport. For example, changes to Swiss law have led to a number of prosecutions in the country's civil courts (FIFA, doping and other affairs, see Chappelet 2010). Investigations have also been carried out by prosecutors in countries hosting sports events and French prosecutors have looked into the affairs of the IAAF (the accused IAAF president was resident in France). In 2016, Brazil's justice department brought charges in a case of ticket-touting involving an IOC member and a Brazilian court ordered the seizure of Olympic Broadcast Services' assets after the company was accused of breaking labour laws at the 2016 Olympic Games in Rio de Janeiro.

Most significantly, US law is playing an ever more important role in international sport. For example, it was the US Department of Justice that ordered the arrest of a dozen FIFA 
executives in Switzerland and, in 2016, the US attorney's office for the Eastern District of New York started investigating allegations of doping at the 2014 Winter Olympics in Sochi, Russia. American prosecutors are able to do this thanks to the Racketeer Influenced and Corrupt Organization (RICO) Act, which extends their jurisdiction well beyond the United States under certain circumstances (Henning 2016).

\section{Improving the regulation of international sport: a possible solution}

The growth of sport during the twentieth century led to misconduct in areas other than spectator violence (hooliganism), doping and match-fixing, which, as noted in the previous section, are subject to international conventions and, once these conventions have been ratified, to provisions of national laws passed thereafter. Although many forms of financial corruption are covered by the anti-corruption conventions drawn up by organizations such as the United Nations, Council of Europe and Organization for Economic Cooperation and Development, corruption in (private) sport organizations can take many non-financial forms, including using inducements to influence the attribution of sports events, the trafficking of children and the violation of workers' rights, etc. All of these issues affect the integrity of sport and damage the credibility sport needs in order to generate revenues through ticket sales, sponsorship and broadcasting rights (Pound 2016).

Several authors have suggested ways of combating these problems and thereby improving the regulation of international sport. In 2014, the IOC created an internal Ethics and Compliance Office (in addition to its Ethics Commission, set up in 1999). Chappelet (2011) argued for the creation of an Olympic accountability watchdog, and the World Anti-Doping Agency used the 2011 European Union Sports Forum to call for the creation of a global anti-corruption agency (Harris 2011). Launched in April 2016 under the auspices of the International Centre for Sport Security (ICSS 2016), the Sport Integrity Global Alliance (SIGA) has published its Universal Standards of Sport Integrity (October 2016). Also in 2016, the IOC set up a Joint Integrity Intelligence Unit in order to monitor and assess any potential unethical activities at the Rio Olympics, as was done with respect to match-fixing for London 2012 (Chappelet 2015). Three British and Irish boxers were reprimanded for betting on the Rio 2016 boxing competitions, even though they were not participating (Ingle 2016). Finally, in February 2016, the IOC launched its International Sports Integrity Partnership (ISIP) at a major conference in Lausanne.

Although these initiatives have their value, they have not managed to involve the world's national governments, without which levels 4 and 5 of Pérez's governance model cannot be implemented. A more effective solution than voluntary 'alliances' or 'partnerships' would be to adopt an international convention linking national governments and sports organizations in the same way that the Geneva Conventions bring together signatory states and the governmental and non-governmental bodies that make up the International Red Cross and Red Crescent Movement (IRCRCM).

These Conventions were drafted in 1949 on the basis of the 1864 Geneva Convention, signed when the International Committee of the Red Cross was formed, have now been ratified by 188 countries (against 183 countries for the UNESCO anti-doping convention in 2016). They lay out the framework within which the IRCRCM operates and cover the humanitarian rights of soldiers wounded during wars, shipwreck victims, prisoners of war and civilians in enemy-controlled territory. 
One or more conventions (which could be known as the 'Lausanne Conventions' in honour of the role this city has played in the development of international sport) could be drawn up to provide an international legal framework, in the sense of Pérez's model (2003), for world sport that would combat the 'dark side of sport' and promote its 'bright side'. Such a Lausanne convention could create a body to audit sports organizations, as discussed in the second part of this article.

\section{Conclusion}

Adequate sports governance cannot exist without greater government involvement in regulating international sport and, consequently, national sport. Only governments can provide a national legal framework (fifth and final level of Pérez's model of governance) and prepare the ground for drawing up a treaty or convention as the basis for international sports legislation. Such a treaty is becoming increasingly indispensable for a global sector with many cases of misconduct in several areas, including doping, match-fixing, hooliganism, racism, human rights violations and corruption. This regulation must respect the autonomy of sport organizations, as recommended by the Council of Europe's European Sports Charter. In terms of the integrity of sport, guaranteeing the 'responsible autonomy' of sport organizations, most of which are nonprofit organizations, in exchange for adequate governance is arguably the best compromise between state and private control.

The alternative of state control is not realistic in so far as national governments have other priorities than sporting activities and performance (which would, in that case, be managed by public bodies rather than nonprofit associations) and do not have the means to finance sports activities (which are currently self-financed by the revenues from major sporting events, most notably the Olympic Games). The privatization of activities linked to sporting performance could be envisaged, as is the case for several sports in North America, but this would quickly turn sport into a branch of the entertainment industry. In fact, the United States' major professional leagues (MLB, NBA, MLS and, more recently, NFL) are for-profit corporations subject to taxation. Following a proposal put forward by an MP from Zurich named Cédric Wermuth (2016), Switzerland's parliament could soon debate the issue of how major IFs are taxed and the possibility of changing their legal form.

Hence, sport organizations and their governance are destined to combine elements of corporate governance (from the private sector) with aspects of democratic governance (from the public sector), as shown in Figure 1. Only intergovernmental treaties can provide the international legal framework needed to oversee this new form of sport governance. Benefits and drawbacks of such a convention or conventions should be further studied.

\section{Disclosure statement}

No potential conflict of interest was reported by the author.

\section{References}

AFP. 2015. FIFA and IAAF Scandals Warning for Corrupt Sports Administrators, December 30. Accessed October 1, 2016. www.dawn.com/news/1229640 
AIS. 2015. Australian Mandatory Sports Governance Principles, June. Australian Government, Australian Sports Commission. Accessed October 1, 2016. www.ausport.gov.au/supporting/ governance/mandatory_sports_governance_principles

ASOIF. 2016. ASOIF Governance Task Force (GTF) - 1st Report to ASOIF Council. Lausanne: Association of Summer Olympic International Federations.

Bevir, M. 2010. Democratic Governance. Princeton, NJ: University Press.

Chappelet, J.-L. 2010. The Autonomy of Sport in Europe. Strasbourg: Council of Europe Publishing.

Chappelet, J.-L. 2011. “Towards Better Olympic Accountability.” Sport in Society 14 (3): 319-331. doi:10.1080/17430437.2011.557268

Chappelet, J.-L. 2012. "From Daily Management to High Politics: The Governance of the International Olympic Committee." In The Handbook of International Sport Management, edited by L. Robinson, and R. Palmer, 7-25. London: Routledge.

Chappelet, J.-L. 2014. "Une vie consacrée au sport: Juan Antonio Samaranch [A Life Dedicated to Sport: Juan Antonio Samaranch].” In Les grands dirigeants du sport [The Leaders of Sport], edited by E. Bayle, 237-252. Bruxelles: De Boeck.

Chappelet, J.-L. 2015. “The Olympic Fight against Match-fixing." Sport in Society 18 (10): 1260-1272. doi:10.1080/17430437.2015.1034519

Chappelet, J.-L., and M. Mrkonjic. 2013. Basic Indicators for Better Governance in International Sport (BIBGIS): An Assessment Tool for International Sport Governing Bodies. Lausanne: IDHEAP Working Paper, 1/2013.

Council of Europe. 1985. European Convention on Spectator Violence and Misbehaviour at Sports Events and in Particular at Football Matches, August. Strasbourg: Council of Europe.

Council of Europe. 2014. Convention on the Manipulation of Sports Competition, September. Macolin: Council of Europe. This Convention was Totally Revised in 2016.

Council of Europe. 2016. Convention on an Integrated Safety, Security and Service Approach at Football Matches and Other Sports Events, July. Strasbourg: Council of Europe.

EOC. 2001. Statement of Good Governance Principles, "The Rules of the Game" First International Governance in Sport Conference, January. Brussels.

EU. 2000. Nice Declaration on the Specific Characteristics of Sport and Its Social Function in Europe, Adopted by the European Council in Nice.

EU. 2013. Principles of Good Governance in Sport, September. Deliverable 2, Brussels: Expert Group "Good Governance".

Geeraert, A. 2015. Sports Governance Observer 2015: The Legitimacy Crisis in International Sports Governance. Copenhagen: Play The Game.

Gibson, O. 2016. "Fifa's Independent Audit Committee Chairman Resigns in Protest at Reforms." The Guardian, May 14.

Harris, N. 2011. "Head of WADA Calls for Global Anti-corruption Body." Sporting Intelligence, February 23. www.sportingintelligence.com/2011/02/23/head-of-wada-calls-for-global-anticorruption-body-230201.

Henning, P. J. 2016. "Road Map for Pursuit of Soccer Charges." International New York Times, June $29,14$.

Henry, I., and P. C. Lee. 2004. "Governance and Ethics in Sport." In The Business of Sport Management, edited by J. Beech and S. Chadwick, 25-42. Harlow: Prentice Hall.

HMG. 2015. Sporting Future: A New Strategy for an Active Nation, December. London: Her Majesty's Government.

ICSS. 2016. New Sport Integrity Global Alliance (SIGA) Launched, April. Madrid. Accessed October 1, 2016. www.theicss.org/en/news/read/new-sport-integrity-global-alliance-siga-launched

Ingle, S. 2016. "IOC Reprimands British and Irish Boxers for Betting on Rio Olympics Bouts." The Guardian, September 28.

IOC. 2008. Basic Universal Principles of Good Governance of the Olympic and Sports Movement. Lausanne: International Olympic Committee.

IOC. 2015. IOC Executive Board Adopts Declaration on Good Governance in Sport and the Protection of Clean Athletes, Press Release, 15 December. Accessed October 1, 2015. www.olympic.org/news/ ioc-executive-board-adopts-declaration-on-good-governance-in-sport-and-the-protection-ofclean-athletes 
Mallin, C. A. 2011. Handbook on International Corporate Governance: Country Analyses. 2nd ed. Cheltenham: Edward Elgar.

Pérez, R. 2003. La gouvernance de l'entreprise [Corporate Governance]. Paris: la découverte.

Pieth, M., ed. 2014. Reforming FIFA. Zurich: Dike Verlag.

Pound, R. 2016. "If Football Doesn’t Get a Grip, Fans Will Turn off the Money Tap." The Telegraph, September 30.

SE. n.d. Sport England Sport Governance Strategy: On Board for Better Governance. London: Sport England.

Tonello, M. 2011. "Separation of Chair and CEO Roles." Harvard Law School Forum on Corporate Governance and Financial Regulation, September 1, Accessed October 1, 2016. https://corpgov. law.harvard.edu/2011/09/01/separation-of-chair-and-ceo-roles/\#2b

UK Sport \& Sport England. 2016. A Charter for Sports Governance in the United Kingdom. London: UK Sport \& Sport England.

UNESCO. 2005. International Convention against Doping in Sport, October. Paris: United Nations Education, Science and Culture Organisation.

United Nations. 2003. Convention against Corruption, October. New York: United Nations.

Wenn, S., R. Barney, and S. Martyn. 2011. Tarnished Rings: The International Olympic Committee and the Salt Lake City Bid Scandal. Syracuse: Syracuse University Press.

Wermuth, C. 2016. Fédérations sportives internationales. Conséquences d'un changement de la forme juridique [International Sports Federations: Consequences of a Change of Legal Form]. MP Intervention of 16.06.2016. 